\title{
Position of Caste in India
}

$\mathrm{A}^{\mathrm{N}}$

instructive review of a situation difficult to gauge with detachment was prepared by Sir Claude Hill for the Friday evening discourse on "Society and Caste in the India of To-day" which was to have been delivered at the Royal Institution on March 9. The discourse was never delivered, for Sir Claude was taken ill and died on April 20, but it is now available in the Proceedings of the Royal Institution, vol. 28, pt. 2, p. 251. It is generally admitted that the present reaction of Hinduism to the introduction of Western conditions and ideas and its effect on the future of the caste system is one of the most important, and at the same time obscure, factors in the Indian political situation.

Sir Claude, in his preliminary account of the origin and characteristic features of caste, lays stress on the fact that this system, imposed for the preservation of the racial purity of the invading Aryansa function which he aptly compares with that of the restrictions laid by Moses on the Israelitesnotwithstanding efforts at reform such as Buddhism, Brahmo Samaj and other movements which he mentions, has adhered rigidly to its main purpose in the demarcation of the grades of society and the regulation of their intercourse. He refers more particularly to two examples which show the strength of caste feeling as against considerations which in other circumstances might be expected to carry preponderant weight. Of these, one is the remarkable position of the Chitpavan Brahmins, who, although they are said to have originated from castaways on the west coast, a tradition supported by their physical characters, have attained a dominant position in Brahminism on the strength of their claim to have sprung from the head of Brahma. The second instance is that of Mr. Gandhi, who, not being a Brahmin, but a Banya by caste, after attaining a position of pre-eminence in leadership such as has not been known for centuries, lost influence entirely when he took up the cause of the Untouchables, not as a political measure, but as an attack on the caste system.
There is, Sir Claude goes on to point out, a curious paradox in modern India. Young India, the intelligentsia class, has imbibed the democratic ideas of John Stuart Mill and Marx, yet clings with an almost fantastic tenacity to the ancient garment of Hindu social philosophy. Superficially, the West has made its mark on the face of Indian society. Sir Claude, in common with other observers, noted the marriages into higher and lower castes or even outside the pale of caste, the ignoring of caste in travel on railways and other like unwelcome departures from 'the ordained path'; but he holds that it would be a mistake to regard these incidents as portending any fundamental change of outlook on the part of the overwhelming mass of the people.

Sir Claude very rightly points to the unchanged position of the village Brahmin, upon whom in the rural community, who form 90 per cent of the population, Hindus of every caste depend for the ceremonial observances which accompany every stage of their life from the cradle to the grave. The undoubted revolt against Brahminical dominance is, he maintains, entirely confined to the political arena, but in the social field the situation remains substantially the same.

On the other hand, while emphasising the extent to which the Indian political problem during the past four years has been complicated by the caste system, Sir Claude also stresses the fact that many highly cultured Brahmins in various parts of India are making noble efforts for social reform by endeavouring to modernise traditional prejudices. Social reform is being advocated by all grades of Indian society, but the leaven is working slowly, especially when compared with the rate of political change. In summing up the position, Sir Claude was of opinion that contact with the outside world will in course of time produce a transformation, but that in so far as we of the Western world are concerned, our help will best be given by an attitude of sympathetic understanding.

\section{International Universities Conference at Oxford}

$\mathrm{T}$ HE Association of University Teachers took the initiative in convening an International Conference of university representatives which took place at University College, Oxford, on June 29-July 2. The conference was called for the discussion of general problems of university organisation and development in the light of the experience of different countries and it was, so far as is known, the first definite effort to establish some measure of international association between universities for the specific purpose of considering university affairs.

Forty universities abroad and in the Dominions appointed delegates to attend the Conference, as well as certain university associations, while British universities were represented by the Council members of the Association of University Teachers and by delegates from Oxford, Scotland and the British Federation of University Women. It was gratifying to observe that among the foreign representatives were included the presidents of both the French and the German University Federations and the vicepresident of the Association of American Professors.

The proceedings began with a dinner in University College on June 29 , at which the foreign delegates and those of Oxford, Sir Michael Sadler and Mr. George Smith with the Warden of All Souls College, were the guests of the Council of the Association of University Teachers.

The first day of the Conference was devoted to a series of accounts of the origin, constitution and aims of the university associations which already exist, given by representatives of each association. These included associations in England, Scotland, France, Germany, the United States, Hungary, Switzerland and Mysore ; but the Swedish and Italian associations unfortunately could not be represented.

It is evident that the principle of association between teachers in universities is of recent origin and has not yet spread far, but in each of the cases mentioned the existing associations are flourishing and useful institutions, keenly appreciated by their members. It is to be hoped that the publication of this series of reports may do something to encourage the foundation of similar associations elsewhere.

On the second day the Conference divided into four commissions, dealing respectively with : (1) overcrowding in universities; (2) vocational training in universities ; (3) co-ordination of the machinery 
of interchange of teachers ; (4) adult education in the universities. Reports from these sections were presented by the sectional leaders to the Conference for discussion on the last morning.

In general, it may be said that there was abundant evidence of interest in the very varied experiences and opinions revealed in these informal discussions. At a first conference the procedure must obviously be exploratory, but nevertheless there was a movement to set on foot international committees to deal with both of the questions, overcrowding and exchange, in which concerted action seems to be specially indicated.

These committees were not actually instituted by the present Conference, which felt that the ground should be explored further with fuller material in hand before action is taken. In order to prepare for this, the Conference resolved that an International Conference Committee should be instituted and that the university associations in each country, or single national universities where such exist, or ad hoc committees in other countries, be invited to nominate an officer to act as a member of this committee, the duty of which will be to maintain international contacts and prepare material for future conferences. Prof. R. C. McLean of University College, Cardiff, was appointed by the Conference to act as secretary of this committee.

The Conference then agreed to accept provisional invitations from France for 1935 and from Germany for 1936 as the scenes of the next two Conferences.

The Warden and fellows of All Souls gave an evening reception at which the Vice-Chancellor, who was unavoidably absent from Oxford, was represented by the Right Hon. H. A. L. Fisher, the Master of New College. The Conference was concluded by an address from Prof. Gilbert Murray, in which he emphasised the duty of university people to uphold ethical standards and freedom in the pursuit of truth.

The movement thus initiated promises well for the future co-operation between universities in different lands, and it is greatly to be hoped that these periodical conferences will establish themselves as a permanent and valuable feature of international organisation.

\section{Sixteenth International Congress of Agriculture}

$\mathrm{T}$ HE sixteenth International Congress of Agriculture was held at Budapest on June 13-20 under the presidency of the Marquis de Vogue, president of the International Commission of Agriculture, and was attended by about 1,100 members. The fifteenth Congress had taken place at Prague in June 1931 and the fourteenth at Bucharest in 1929 , it having been the intention up to the present to convene such gatherings every two years. Actually ten meetings took place prior to the War, and a further six have taken place since. The seat of the international organising committee is at Paris where the inaugural meeting was held in 1895 , to be followed by a second (which actually, however, must rank as the first proper) meeting at Budapest in 1896, which year marked the thousandth anniversary of the existence of Hungary as a nation.

Consequently, after an interval of thirty-eight years, Budapest has been once more chosen as the venue for the Congress. At the preceding one, held at Prague, attention was focused on the then most pressing problem of the moment, namely, the agricultural crisis and methods to be recommended for combating it and minimising its evil effects. The programme of work at the recent Congress was subdivided into eight sections, namely, (1) agricultural economics, (2) rural education, (3) co-operation, (4) crop production, (5) viticulture, (6) live-stock production, (7) agricultural industries and (8) con. sideration of the part played by women in the farming community and in farming life.

The principal paper in section 1 was that by Prof. Ernest Laur, director of the Union suisse des paysans, on the reorganisation of present-day agriculture and, in view of the persistence of the agricultural depression in almost all countries of the world as well as the severity of its incidence, the subject of his contribution must be considered as the principal and most important topic discussed at this Congress. Prof. Laur, at the conclusion of his paper, put forward various recommendations, forming part of a proposed agricultural policy, amongst which were that the consumption of fats of animal origin, and especially butter, should be encouraged by private or State measures in order to combat the growing consumption of vegetable fats, which in turn has restricted the consumption of cereals and been one of the principal causes of the accumulation of cereal stocks with resulting price debasement.

The other papers in section 1 dealt with the in fluence of mechanisation on agriculture and with the organisation of a proposed international live-stock market.

At the Prague Congress the attendance was about 1,200, including 563 participants from European countries other than Czecho-Slovakia and from nonEuropean countries, and this total represented the highest attendance reached at any meeting held up to date. The Budapest Congress showed an attendance of 72 official delegates of various Governments, 19 delegates representing international organisations, and about 1,028 individual members. Great Britain was only represented by some fifteen of the latter and such a poor representation is, in the opinion of the writer of this article, very much to be regretted, the more especially as the same state of affairs prevailed at the two previous congresses at Bucharest and Prague.

Most of the countries taking part in these congresses are, in the main, agricultural exporting countries, whereas England is, as is well known, a heavy importer of agricultural produce. In order therefore that her views and difficulties as such should be properly stated and justified, it is essential that she should be adequately represented at these international congresses, which assume more and more importance as time goes on. Failure to do so is liable to result in judgment going by default.

At the termination of the Congress a choice of agricultural excursions was offered to all members, that to the Hungarian university town of Szeged and to the Government stud farm at Mezöhegyes being of especial interest.

At the closing session the Congress resolved that from now onwards meetings should be held at intervals of three instead of two years, as previously intended, and that the venue for the next congress should not be decided until next year. 